\title{
Kwame Nkrumah's Consciencism, Marxism and the Dialectics of Change in Africa
}

\author{
Matthew Dayi Ogali PhD \\ Department of Political \& Administrative Studies, Faculty of Social Sciences \\ University of Port Harcourt, Port Harcourt \\ Matthew.ogali@uniport.edu.ng
}

\begin{abstract}
Africa has, over a long historical period, spanning several centuries, been exposed to a myriad of influences, mostly negative, from Euro-American West, the Judeo-Christian religion, Oriental-Islamicincursion from the Middle-East and Indo-Confucian China, India and South East Asia, all of which have reshaped the African personality so much that the original African egalitarian culture appears almost completely submerged. This is a study on the interpretation, relevance and applicability of Kwame Nkrumah's philosophy of Consciencism as the driver of the dialectics of change and development in Africa. The Marxist theory of historical materialism or the materialistic interpretation of history was adopted as the theoretical framework. Data sourcing was mainly from secondary sources and analysis based on content analysis of materials of the philosophy of consciencism. It was found that the philosophy of consciencism was the product of Nkrumah's frustration with the developmental inertia in Africa. Conclusively, the paper acknowledged the relevance of the philosophy of conscienscism but, however, recommended a re-evaluation of the philosophy to accommodate some contemporary realities in Africa, particularly the existence of social classes, as a means of enhancing its applicability to the development of Africa. Keywords: Consciencism, Philosophy, Development, Socialism, Egalitarianism
\end{abstract}

DOI: $10.7176 /$ RHSS/12-4-06

Publication date: February $28^{\text {th }} 2022$

\section{Background to the Study}

Both during the colonial and post-independence periods, and despite its enormous potentials in terms of natural, physical and human resource endowment, Africa still lagged far behind other continents of the world in comparative development terms. Passing through the slave trade, plundering of its resources under 'legitimate commerce' and then colonial rule Africa appeared to be stricken with a developmental paralysis that became the attraction of global intellectual attention and hence the framing of developmental models as well as the packaging of financial inducements in form of aid, which rather drove the continent even deeper into the abyss of underdevelopment. The totality of Western efforts to instigate economic development in Africaturned out to be a mere advancement and reinforcement of imperialistic plundering aided by intellectual hegemonic domination by the advanced capitalist countries (Baran, 1957; Frank, 1967; Emmanuel, 1972; Rodney, 1972; Brett, 1973; McLellan, 1980; Onimode, 1983; Gramsci, 1999, Ake, 2000). Ironically, the same predators presented themselves as the saviour armed with several developmental models, theories and perspectives for Africa. Chinweizu (1978), Fanon (1985), Ake (2000) and several other Third World scholars have enigmatically demonstrated the subjectivity of western scholarship which constituted a form of intellectual imperialism by cleverly avoiding the ethical violence perpetrated on the psyche of African leaders, statesmen and citizens. Following the same line of reasoning Nkrumah arrived at the conclusion that an intellectual paradigm shift had become necessary and even exigent to create a distinct path for the development of Africa taking into cognizance its historical and objective peculiarities.

Nkrumah's philosophy of Consciencism aimed to redefine the African personality that has already been tainted by Western, Islamic, and Euro-Christian elements by molding these elements into one with the traditional African conscience and deploy it to chart a new direction for Africa's development both ideologically and materially. Such a theoretical would sound like seeking liberation and integration simultaneously, accommodating a socio-cultural phenomenon and at the same time rejecting a seeking liberation from it, an apparently impossible ideological and functional mission. Nkrumah (2004) had in another courageous work enumerated the destructive capacity of western imperialism, in form of colonialism, and neo-colonialism.

The philosophy of Consciencism is also materialistic in content (Nkrumah, 1969).It believes in the "absolute and independent existence of matter". It is also dialectical and dynamic in operation, i.e. "the capacity of matter for spontaneous self-motion" (Nkrumah, 1969, p. 84). The materialism of the philosophy of Consciencism is not one that asserts the sole existence of matter, but rather it recognizes the realm of ideas, consciousness, spirit or mind as an aspect of matter or reducible to matter. In other words, consciousness is not independent of matter. The categories of mind and matter are accepted as real and interact with each other in a dialectical sequence, but matter enjoys a primacy of existence over mind or spirit.

The dialectics of consciencism consists in an interplay of matter and mind resulting in the emergence of a 
higher state. This is a continuous and spiral process that produces higher states of existence sequentially. Thus, matter and mind are seen as opposing forces which opposition is resolved by the emergence of a higher state of being or existence. Mind and matter are therefore not parallel forces working in isolation from each other or working independently one from the other but rather interact mutually and this interaction is the germ of progress or development. However, this should not be interpreted to mean that matter and mind are distinct categories but rather that mind or idea or consciousness consists in matter and since matter is capable of selfmotion the dialectic operates within matter itself as the primary element which produces a mind consistent with it.

There is an observable problem here because Consciencism is referring to two types of change. One refers to a change generated as a result of the interaction between two forces: mind and matter. He asserts that: "Material objects and their properties belong to different logical types, and so do material objects and mind ... Since matter is a plenum of forces in tension, and since tension implies incipient change, matter must have the power of self-motion original to it. Without self-motion dialectical change would be impossible" (Nkrumah, 1969, p. 90). The locus of this dialectical change therefore becomes difficult to locate - whether in self-motion of matter or in the interaction between matter and mind or both. Nkrumah himself recognized this problem which he called "categorical absurdity". By translating this philosophical thought to his brand of socialism we shall show later, in this paper, how this absurdity is inevitable.

\section{The Problem}

Kwame Nkrumah's Consciencism could be defined as a philosophical and ideological construct derived from traditional African egalitarianism fashioned specifically for the purpose of guiding the de-colonization and transformation of Africa from backwardness to modernity. This philosophical system is based on certain assumptions. First, that every social epoch in the development of human society is held or bound together by a system of intellectual, ideological and philosophical thoughts which legitimize the prevailing system. In a period of fundamental change or revolution it is necessary to generate new ideas to disprove the earlier ideas and map out the new direction of thinking in the minds of the people in favourof the change and the new or emerging society. Third, that, traditional African societies were essentially classless and therefore communist in both orientation and character. Fourth, that Africa was evolving its own peculiar brand of socialism, a societal evolution different from that defined by Marx, prior to the imposition of capitalism. Consequently the impending transformation in Africa should be directed toward the development of this brand of socialism, called African Socialism. This is not to say that the change is entirely ideological but that it must of necessity be complemented by an ideological/philosophical change.

This paper seeks to theoretically address three related problems. First is the perception that the suitability and practicability of Nkrumah's philosophy of consciencism as an ideological paradigm to drive the process of development in Africa and across the Third World is unclear and questionable. Some of the fundamental assumptions of the philosophy are not in consonance with the reality of the African developmental condition. Second, Consciencism draws inspiration from Marxism but at some strategic point appears to proceed on a developmental trajectory that contradicts the Marxist-Socialist path, thus raising doubts about its contemporary relevance. Third, is its denial of the existence of social classes in contemporary Africa, based on the concept of African socialism, i.e. the argument is that Africa is already originally egalitarian and socialist and need no other brand of socialism. Fourth, the feasibility of Consciencism's projected enterprise to weave together the various external influences from the West, Asia and the Middle-East, into a new philosophy of development for Africa is doubtful.

\section{Aim and Objectives of the Study}

Broadly, the study aims to interrogate the theoretical and philosophical elements of Nkrumah's Consciencism as they relate to the need for a fast pace of socio-economic and political development in Africa as well as an indigenous model or path to development that is unique to Africa. The specific objectives are to:

1. Interpret and explain the various theoretical elements contained in Nkrumah's philosophy of Consciencism.

2. Critically examine the fundamental assumptions of the philosophy of Consciencism in relation to the historical evolution African culture.

3. Interrogate the suitability and applicability of Nkrumah's philosophy of Consciencism as a guide to Africa's development.

\section{Research Questions}

1. What are the various theoretical elements contained in Nkrumah's philosophy of Consciencism?

2. What is the relationship between the fundamental assumptions of the philosophy of Consciencism and the historical evolution African culture? 
3. How suitable and applicable is Nkrumah's philosophy of Consciencism as a guide to Africa's development.

\section{Theoretical Framework}

Marx's theory of historical materialism or the materialistic interpretation of history is suitable to serve this study as its theoretical framework, because the philosophy of consciencism itself lays a claim to being a materialistic philosophy which gives priority to matter operating in a dialectical interaction with idea or consciousness. The material condition of living provides the basis for abstract conceptions or ideas such as religion, tradition and interpretations of the physical world and social phenomena. Marx (1977) wrote that it is not the consciousness or thoughts or perceived ideas of man that determine his being but rather it is his social being, objective or physical experiences, encounters or reality, that determine his consciousness (Ake, 1981; Ekekwe, 2009; Ogali, 2021).

Africa's socio-cultural evolution has been determined by the objective realities manifesting from the physical environment as well as their social interactions in the process of production.From this mode of production had arisen modes of thought, a culture, religion, a social structure and a political system of power division. Such an interpretation of Marxism has beenconsidered Eurocentric and economically deterministic, where economic 'laws' determine the history of humanity and human societies and where the economy determines other aspects of human life (Selwyn, 2013, pp. 48-70). However, a dialectical perspective of Marxism views the process human historical development as the result of the constant interaction between these various spheres. It is the science of the general laws of motion as they manifest in the process of development of natural phenomena, human society and thought or ideas or consciousness (Engels, 1976).

Like Marxism, consciencism is not only materialistic but also dialectical, though some points of divergence are identifiable as will be discussed below. However, the fact of both Marxism and consciencism adopting materialism and the dialectics proves the suitability of the theoretical framework for this study.

\section{The Philosophical Elements in Consciencism}

Nkrumah used all the early chapters of the book to show that every philosophical system or thought, no matter how abstract, could be reduced to 'the social milieu, which produced it'. Philosophy is concerned fundamentally with the explanation of the origin of things or existence. He refers to it as the question of 'what there is' and how 'what there is' may be explained. Starting from Thales, the earliest known Western philosopher who held that 'water' was the primary substance of things, and Berkeley, to whom the world consisted of 'spirits' and ideas'. In other words, these were what primarily constituted whatever is or exists and that whatever exists is reducible to these primary substances. The next question is the source or origin of this primary element. How did this first or primary thing come into being or what caused it? That is to say what is the 'basic raw material' of this primary element? It is either part of the basic raw material or the product of it. This means that if one argues that it is part of it then one is an atheist, i.e. to take the position that the world produced itself or evolved on its own.

Conversely, to argue that it is a product of the 'basic raw material' makes one a deist. This would be the same thing as arguing that the world created was by a body external to it. This kind of argument clearly has theological roots and Nkrumah sees a dialectical contradiction in it. He even relates it to the African societies. He says that the twin problem of 'cause' or 'uncause' could be used to explain our religious conception of the origin of the world, whether it was brought into being from outside, i.e. by God, or it evolved from inside on its own. He sees a dialectical interplay between these as well as a conversion process in which God creates the world and then converts Himself into man. Furthermore, this process is reversible as man following Christianity, is expected to live, move and have his being in God. But a contradiction is created here in which physical man neglects the physical or material circumstances surrounding him and focuses on things outside the physical world. This is the basis of Marx's criticism of religion, which helps to divert man's attention from the surplus value he has created to be exploited by another.

Nkrumah then locates this argument socially within the African context. While arguing that traditional African societies de-emphasized this 'inside' and 'outside' contradiction and treated them rather along a continuum, he goes on to state that the contradiction has a great deal to contribute to the process of decolonization and the struggle against imperialism. This is because following Marx he sees this Christian attitude of concentrating on the 'outside' and neglecting secular concerns as diversionary and helps to facilitate the exploitative designs of the colonialists and imperialists. But there is another internal contradiction in which religion becomes an instrument of bourgeois manipulation of the masses particularly when a dialectical opposition between church and state begins to be entrenched. This is a situation that can greatly impede the decolonization process. For this reason, he insists that the state must be secular. He attributes religion to poverty, misery and 'terrifying pauperism' under the yoke of capitalism, colonialism and imperialism. In other words, the poorest in society are also the most religious. Taken to the international level the poor countries of Africa, Asia and Latin America are also the most religious. Therefore, the more affluent a society or individual the less religious it/he becomes and vice versa. It must be said here that Nkrumah stands on a very weak theoretical 
position in attacking religion. The position of Marxism is understandable because it seeks to achieve socialism by revolutionary means which religious attitudes tend to weaken. But for consciencism, which rejects the revolutionary path to socialism, the effect of religion has to be properly located. It is not enough to hide under Marxist doctrines to attack religion, while at the same time rejecting the Marxist method and strategy. The effect of religion on non-revolutionary change cannot be the same as that on revolutionary transformation to socialism.

Nkrumah returns to the philosophical problem of idealism and materialism. In idealism spiritual factors are recognized as being primary and matter held to be dependent for its existence on spirit. This is the position, in various ways of philosophers like Leibniz and Berkeley. While Berkeley sees the world as being possessed by spirit, to Leibniz matter is really unconscious spirit. In other words, the physical world is not just possessed by spirit but really spirit. Idealism is actually sustained by solipsist perception. Solipsism is the idealist philosophy in which 'the individual is identified with the universe. The universe comes to consist of the individual and his experience" (Nkrumah, 1969, p. 16). In this system only oneself exists and other things exist as one's experiences. Descartes holds an extreme view of this position in which one can actually think of oneself without a body. Here, everything, which might be known through the sense or through reason, comes into doubt because the senses sometimes suffer from illusions and delusions, and could actually be part of dream experience. Therefore, they are unreliable witnesses to truth, the truth and what really exists, his experiences. The other arm of idealism is perception. Here,

the idealist holds that we only know of the external world through perception; and if matter be held to be constitutive of the external world, then we only know of matter through perception ... Granted that perception is a function of the mind or spirit, matter ends up depending on spirit for its existence" (Nkrumah, 1969, p. 18).

Nkrumah refutes idealism for the simple reason that perception takes place through the agency of the senses, and senses are capacities of the living organic body. Therefore, perception cannot exist or operate independently of the body, which is matter. He also rejects solipsist idealism for the fact that if one can think, then he also lives, and if he lives then it is the living being that actually exists, and if one exists others also exist. This makes it impossible for the living being to think himself out of existence, because the thoughts or ideas can only be the product of the mental activities of the living being which should be primary.

At the level of materialism where philosophical consciencism claims to belong matter is said to exist independently of mind. This is to assert the thesis in its simplest form. However, it is more complex than this as it raises some serious philosophical questions. Within materialism there is the assertion of the sole reality of matter. That is to say that matter exists solely and independently: on its own. In this sense matter does not recognize the independent existence of mind or spirit or consciousness. This appears to be an extreme view of materialism. It is materialism taken to the extreme. A more moderate position is that which claims the primary reality or existence of matter over mind. This position recognizes the existence of mind or spirit or consciousness but makes matter, the primary substance on which consciousness or mind depends for its own existence and from which it is derived.

Continuing Nkrumah introduces the distinction between consciousness and self-consciousness and uses this distinction to explain the dynamics or dialectics of matter. Consciousness is an overt response to stimuli while self-consciousness refers to internal experience. What this means is that when matter interacts with mind as the source of stimuli, matter is said to be conscious. But when matter evolves on its own, through its internal forces or experiences, without an external stimulus, it is said to be self-conscious. He states that when 'materialism becomes dialectical the world is not regarded as a world of states, but as a world of processes'. Thus, the philosophy of materialism is dynamic and not static. This dynamism is two-fold, One, it is the result of the interaction between mind and matter and, two, the result of the internal processes of matter itself.

\section{Consciencism and African Society and Culture}

Furthermore, Nkrumah relates philosophy to society. He argues, rightly, that philosophy, no matter how abstract it might appear, can be located in the objective reality of society at various levels of its development or evolution. He says philosophy had its origins in religious speculation. Early philosophers were concerned with speculations about the nature or God, of the human Soul, Destiny, and Divine Law. This was in ancient times when religious life was one of the major concerns of human existence. This was a period when religion and worship constituted the most primary every-day preoccupations of man. Man cultivated the gods in the same way as he cultivated his crops. The gods were effectively linked to agriculture and all other strands of human existence.

All this was to change however during the European Renaissance period when man became the centre of the universe. The workings of the human mind in fixing what were its limits of reality became the preoccupation of philosophers. One shining example of this trend was Immanuel Kant and his philosophy of rationalism. Rationalist philosophy sought to keep reality within the parameters of human reason. Engels (1978, p. 19) once chided that 'everything had to justify its existence upon the judgment altar of reason or ceased to exist'

Rationalism coincided with a period in the development of human society when man began to appreciate 
the importance of his personal or individual dignity and freedom.Nkrumah notes that 'sacerdotal power is inevitable' were gods are used to explain nature. This power stems from the relationship between the priests and the congregation and by extension society. Greek states during the classical period were highly religious and the priests wielded enormous religious and political power over both their congregations and society. They alone could determine the divine will in explaining social phenomena. They were so powerful that they could institute action in court on charges of irreligion, as they did against Socrates, because such attitudes tended to endanger the state arid community. By this means sacerdotal power could be translated into political power with philosophy serving to consolidate class divisions. This was the social purpose that philosophy was designed to serve whether deliberately or inadvertently.

However, time came when Greek religion became less congregational and more individualistic. During this period there was also a shift from an agriculture-based economy cc mercantilism. Mercantilist class emerged, which steadily undermined the socio-political power of the priests. This was the social setting, which enabled Thales to completely dispense with the gods in his explanation of social phenomena. Protagoras reinforced this position with the statement that the universe had passed from the hands of the gods into the hands of men.

Thales actually led an intellectual or philosophical revolution, which reflected an already evolving social reality. Thales defended the position of the mercantilist class against the priesthood. Consequently, his choice of water as the basic substance of existence is a curious coincidence as mercantilism thrived mainly along and across the Mediterranean Sea. Nkrumah uses this analysis to confirm his argument that philosophy is usually rooted in society. Also, along this line the philosophical system of Heraclitus, which saw society in terms of the clash of opposing forces was consistent or reflective of the revolutionary eruptions that shook Greek society at the time. Heraclitus explained society in dynamic terms. Opposing tendencies or forces were not destructive but rather constituted the germ for the evolutionary development of society. This clash of opposites is indispensable growth both in nature, society and the entire universe. Nothing can grow or progress without opposing forces actively confronting each other and in the process transforming the object or society into a higher and more progressive level. To him the only thing that is permanent in life is change. However, this philosophical system reflected the revolutions in which the aristocrats overthrew the monarchies.

Returning to the Renaissance with its humanist and rationalist philosophy it is easy to see the capitalist roots in it. Nkrumah distinguishes between a first renaissance and humanism and a second renaissance and humanism; the first represented by Aristotle, who put man at the centre of the universe. He championed an idea, which connected democracy with knowledge, arguing that the truth on any matter has different sides to it and since no single person can have full knowledge of it others have to contribute to the full knowledge of the truth. The state is therefore beset on an interdependence of men pursuing the same ultimate goal. He however did not believe that every man was able to contribute to the truth. To accept that would require equal political rights to everybody, which would not the feasible in a slave-based society. The important point here is that his philosophy reflected the slave-based society of his time.About the second renaissance and humanism represented by John Locke, Nkrumah says;

it raised from the economic sphere the unfeeling competition and pursuit of supremacy which characterize capitalism, and transposed them to a philosophical conception in which each man, armed with his natural and inalienable rights, is pitted against every other man (Nkrumah, 1969 , p. 50).

Both present man as the centre of the universe; man, and not God, as the reference point of political organization, and emphasize the freedom and dignity of man. It should be understood that this philosophical system developed as the bourgeois revolution overthrew feudalism in Europe. The feudal system itself was strengthened by ecclesiastic philosophical thought, in which religious doctrines were used to rationalize the exploitation of the peasantry by the feudal lords and the clergy in Europe.

Returning to the problem of "categorical absurdity", it is this paper's contention that this absurdity is inevitable, particularly in the context of Africa. But Nkrumah tries to wriggle out of it by returning to the connection between thought and practice and between knowledge and action which when separated renders the other ineffective. He also links it with the relationship between ideals and institutions, arguing that since circumstances change, for ideals to be pursued throughout the changing scenes of life it is necessary to modify or even replace institutions in order that the same ideals should effectively be served. With this he introduced egalitarianism as the basic principle as well as a permanent feature of the philosophy of consciencism. In the context of Africa therefore, egalitarianism becomes the foundation upon which his entire philosophical system rests, arguing that in philosophical consciencism ethical rules and values are not permanent but depend on the stage reached in the historical evolution of a society. However, the cardinal principles of egalitarianism are to be conserved, notwithstanding the change (Nkrumah, 1969).

The attempt to build his philosophy upon the principle of egalitarianism is deliberate and consistent with his socialist thought and his brand of socialism, which does not recognize social classes, but what is doubtful is its usefulness for socialist construction. It is noteworthy that Nkrumah's concept of egalitarianism is 'based on the 
monistic thesis of materialism', which views matter as one even in its different manifestations. This is important because Nkrumah's conciencism sees traditional African society as egalitarian not only in terms of freedom and equally but also in terms of unity, cohesion and classlessness.Furthermore, he argues that dialectical processes are not unilinear. They do not follow just one straight line. Here he draws an analogy;

There is a route from any twig of a tree to any other twig, such that the route never leaves the tree. But this does not mean that the twigs all have some one point in common, for it may be necessary to pass to the trunk and join another branch in other to pass from one twig to another (Nkrumah, 1969, p. 96).

This conception of the dialectical process is also significant because it defines Nkrumah's idea of the evolution of human society, particularly the African setting, which aims to achieve socialism from primitive communism without other intervening modes of production like slavery, feudalism and capitalism, not even the Asiatic mode of production. As far as Nkrumah is concerned slavery, feudalism and capitalism did not and do not exist in Africa. This is the basis of his dialectical process as quoted above, which bases social evolution on the self-motion of matter or 'endogenous' change. As Roxborough has observed, this model is derived from the bourgeois analysis of the development of capitalism in Europe, which supposed "a closed system, with some catalytic change occurring within it and then triggering off a sequence of changes which would produce a transition from traditional to modern" (Roxborough, 1979, p. 19). This seems to be the source of Nkrumah's dialectics of social change. It is from a bourgeois source, e.g. traditional to bureaucratic authority (Max Weber), mechanical to organic solidarity (Emile Durkheim), universalism to particularism (Parsons), etc. (McLellan, 1980; Ake, 1981).

As stated earlier, there is a critical point of divergence between Conciencism and Marxism. While he believes in socialism he rejects outright scientific Marxism as the basis for achieving or constructing socialism and communism in Africa. He not only repudiates the revolutionary path to socialism and communism but also the fundamental basis for the revolutionary struggle to achieve socialism, i.e. social classes. He says philosophical consciencism:

is directed at preventing the emergence or solidifying of classes, for the Marxist conception of class structure, there is exploitation and the subjection of class to class. Exploitation and classsubjection are alike contrary to consciencism. By reason of its egalitarian tenet, philosophical consciencism seeks to promote individual development, but in such a way that the conditions for the development of all become the conditions for the development of each; that is, in such a way that the individual development does not introduce such diversities as to destroy or threaten the egalitarian basis of social relationships. The social-political practice also seeks to co-ordinate social forces in such a way as to mobilize them logistically for the maximum development of society along true egalitarian lines (Nkrumah, 1969, p. 98).

Constructing a philosophical system that would prevent the emergence of social categories or social phenomena already in conspicuous existence across Africa where kingdoms with distinct social classes had been in existence prior to European incursion, would sound absurd. If the purpose was to make a populist point it could be conceded,but it would also be overly reactionary in the sense of denying the dynamic basis of social change and revolution, which is the class struggle. However, it must be admitted that it is consistent with his philosophical system, against the backdrop of his ideas about socialist transformation in Africa based on the presumed generalized African egalitarianism.

\section{Philosophy and the Evolution of Human History}

The claim about the ontological priority of matter over ideas informs Marx's approach to understanding the development of morality in human history, providing justification for the methodological materialism he espouses and employs (Wills, 2011). Marx and Engels (MECW, 5, P. 36) explained this philosophical point about the primacy of matter over the idea or consciousness thus:

The phantoms formed in the human brain are also necessarily, sublimates of their material life-process, which is empirically verifiable and bound to material premises. Morality, religion, metaphysics, all the rest of ideology and their corresponding forms of consciousness, thus no longer retain the semblance of independence. They have no history, no development; butmen, developing their materialproduction and their material intercourse, alter, along with this their real existence, their thinking and the products of their thinking. Life is not determined by consciousness, but consciousness by life. In the first method of approach the starting-point is consciousness taken as the living individual; in the second method, which conforms to real life, it is the real living individualsthemselves, and consciousness is considered solely as their consciousness.

Ideological forms of thought or consciousness such as morality or religion are products of human activity in the process of productive activity which, as Marxism espouses, cannot be fully or properly comprehended without a correct interpretation and location of their basis in peculiarcircumstances of the economic, social and 
historical foundations of that society (Wills, 2011).

From a dialectical perspective, human intervention with the material world produces newideas about survival under peculiar environmental conditions that are specific to that society. However, these ideas in turn play a role in shaping material conditions and determining the development of the productive forces. This complex process is the fundamental basis for dialectical interplay, both in terms of negation of the negation (Engels, 1978) as well as the unity between ideas and matter in which matter acts as the dominant force that determines other spheres of human life, though not always (Wills, 2011).

Furthermore, Nkrumah undertakes to show that philosophy is an instrument of ideology. There is a ruling segment or ruling class in every society. There is also a dominant ideology in every society. This is the system of ideas, principles, and intellectual trends, which serve to hold the society together. The ruling ideas in any society are the ideas of the ruling class in that society. This is a clearly Marxist position which Nkrumah has adopted. An ideology "seeks to bring a specific order into the total life of its society" (Nkrumah, 1969, p. 9).This is achieved though political theory, social theory, moral theory, history, literature, art, establishing ethical standards for the whole society. These standards of behaviour are absorbed and internalized by the whole society without being conscious of their class origins and interest.

Different groups, segments and classes can hold different ideologies in the same society but it is the ideology of the dominant class, which rules the whole society that is also dominant and is seen and presented as the ideology of the whole society. Consequently, for that existing system to be overthrown and the entire society restructured, the revolutionary class must also struggle to foist itself on the whole society by presenting its ideology as a better alternative, so that a revolutionary struggle also entails an ideological struggle. Nkrumah specifically identifies history as one formidable ideiogical instrument that has been deployed by the colonialist to suppress Africa. He says;

The history of Africa, as presented by European scholars, has been encumbered with malicious myths. It was even denied that we were a historical people. It was said that whereas other continents had shaped history, and determined its course, Africa had stood still, held down by inertia; that Africa was only propelled into history by the European contact. African history was therefore presented as European history (Nkrumah, 1969, p. 62).

He argues rather that such ideas have been used to justify slavery. Christianity has also been used to suppress African history, culture and civilization. He therefore insists that African history must be rewritten to reflect the culture, tradition and socio-political organization of the African Society.

\section{A Critique of the Philosophy of Consciencism}

In criticizing Nkrumah's philosophy of consciencism one must admit that he was very consistent in rooting his philosophical system in his beliefs about the dynamics of African society. However, the assumptions underlying his analysis of the history and development of the African society are largely misplaced. To begin with, the philosophy of consciencism is based on the assumption that African societies thrived upon the principle of egalitarianism. This suggests that African peoples i.e. kings and subjects related to each other on the basis of freedom and equality. It also suggests that African societies were united, cohesive and classless.

Nkrumah did not just jump at this conclusion. He derived it from his philosophy of consciencism, which is based on the dynamism of the self-motion or self-consciousness of matter. Accepting the Marxist philosophical position of interracial interaction between matter and mind, or idea, or consciousness as the basis for development would lean to the acceptance of the existence of classes or segments or antagonistic forces in society, particularly African society, hence the belief in the self-motion or self-consciousness of matter, which would lead inexorably to the recognition of a non-segmented, united and cohesive African society. It is however strange that Nkrumah sees this self-motion of matter as dialectical, because dialectics would suggest the interplay of two opposing forces. He fails to show these two forces in the doctrine of self-motion, or in the case of African society the dialectical forces at play in the development of the society. Fitch and Oppenheimer (1966, p. 82) have observed that;

the CPP made no effort whatsoever to restructure Ghanaian society: the leaders did not see the institutions left behind by the British colonialists as barriers to national economic development.

The CPP, at this time, believed that in order to achieve rapid economic growth the institutions

of colonialism needed only to be administered by Africans.

Nkrumah's concept of egalitarianism has led him to deny the existence of any contradiction between the structures of colonialism and the pro-capitalist social formations in Africa. Even the objective contradictions between foreign capital and national developmental aspirations of the African State, and that between social classes even in post-colonial Africa are effectively denied. This is obviously misplaced. Capitalism, even in its dependent form as exists in Africa, has engendered a new class structure with the attendant contradictions. The fact that social classes do exist in Africa cannot be easily wished away. Ake (1978, p. 62) has correctly asserted the existence of objective class relations in Africa. Derived from the objective reality is the fact that there are 
those who effectively own and control the means of production and those who do not possess any such property.

Along this line he has identified a class of exploiters 'class position' and exploiters by 'class situation', these two making up the exploiting class. On the other hand, there is the exploited class made up of the urban proletariat, and rural peasantry. This non-recognition of an African society segmented along class lines, an idea based on the principle of egalitarianism, is a grand design to suit his own brand of unscientific socialism. By this rather strange design no distinction or contradiction is recognized between state and private enterprises, or foreign capital and national institutions, all of which could work together for their own benefit as well as for all(Fitch \& Oppenheimer, 1966). Indeed the method of achieving this brand of socialism was no less strange and illusive than the envisaged society self. Borrowing from Mahatma Gandhi of India, Nkrumah's strategy for achieving independence and socialist construction was non-violence'. While recognizing two means of achieving self-government, by armed revolution and othernon-violentconstitutional and legitimate methods, he chose to advocate the latter (Nkrumah, 1957). Regarding socialist construction the position of the Convention Peoples Party (CPP) was clearly stated by J. H. Mensah, Chairman of the National Economic Planning Commission in the Nkrumah Government, He said:

it was impossible to apply a theory dealing with European experience directly to the Ghanaian society. Traditional Marxist theory... is aimed 'at the reorganization of the ownership of existing property'... The real problem to which socialists in developing countries should address themselves is not the rearrangement of the ownership of the means of production. The central concern must be the building up of the nation's stock of productive assets (Fitch \& Oppenheimer, 1966, p. 110).

Nkrumah's brand of socialism is the type Marx has categorized as 'bourgeois socialism'. It is the type of socialism that would be achieved without a revolutionary struggle. It does not recognize the exploitative relations in society. The obvious socio-political and economic inequalities are simply overlooked. Even the increasing poverty and misery of the working class and unemployed are explained away as the result of mismanagement. Society is seen as one bone and one flesh. It is this construct that Marx refers to as the "socialist bourgeois"who desires all the advantages of modern social conditions but avoids the struggles and conflicts that necessarily result from them(Marx \& Engels, 1969, p. 133). They want to enjoy all the products of advanced technology without therevolutionary and transformative elements that would require the proletariat to construct a new society. The proletariat is expected to remain within the confines of existing society, but jettison all ideas or ideologies to overthrow the bourgeoisie.Nkrumah's socialism was clearly destined to fail because of the erroneous and unfounded philosophical and theoretical assumptions upon which it was built. Fitch and Oppenheimer have observed that:

CPP thinking about the transition to socialism is based on three assumptions. The first assumption is that state ownership of certain of the means of production necessarily leads to socialism. The second is that the state sector can overcome the private sector without engaging it in a life-and-death struggle. The third assumption is that foreign private capital will let itself be used to build socialism (Fitch \& Oppenheimer, 1966, p. 113).

It must be stated that Nkrumah was somewhat naive in believing that he could carry along foreign and local capitalists in socialist construction, that they could surrender their wealth without a fight, and that they shared the same socialist aspirations with him. Indeed, these were the same forces that sponsored his overthrow and terminated his socialist pretensions. Marx called this situation "utopian socialism", referring to the desire to improve the condition of every member of society, constantly and ideologically appealing to society at large, without recognizing class distinctions that obviously exist in society. All political, particularly revolutionary action, is rejected, but rather desire to effect change by peaceful means and efforts, or "by small experiments, necessarily doomed to failure" (Marx \& Engels, 1969, p. 135). Hutchful (1980, p. 6) captured the situation in Nkrumah's Ghana very vividly, pointing out that:

the Nkrumah government introduced a series of measures to increase national control over the economy ... Bilateral trade and payment agreements with the socialist countries ... diverted $26 \%$ of Ghana's import trade and $21 \%$ of her exports from external capitalist markets to those of the socialist area. The policy of socialism led to increasing state controls in the economy.

Against this position however an IMP mission that visited Ghana in May 1965 demanded the imposition of a stabilization programme which included cutbacks in government expenditure, cessation of subsidies to state corporations, lifting of the state shipping monopoly, scaling down of trade with the socialist countries, etc. "Nkrumah government rejected the recommendations on 22 February 1966 and two days later the Government was overthrown in a military coup" (Hutchful, 1980, p. 8).

Nkrumah's claim that the philosophy of consciencism is materialistic is also questionable. For a philosophical thought to lay claim to materialism it must base its interpretation of existence or the fundamental content of the life process on a tangible material object. Thales' philosophy can safely claim to be materialistic having reduced the primary substance of existence to a material object-water. In the same vein Marx has also 
reduced the primary life process to the interaction between an object and its natural environment and by extension between man and nature in the realm of production. Here we are dealing with objective material beings. The same cannot be said about consciencism, as the primary element in consciencism was reduced to the conscience of the African based on the principle of egalitarianism. In this case we would be dealing with subjective elements of analysis. Babu (1981, p. 65) confirms this interpretation by stating that; "Nkrumah's consciencism and Kaunda's humanism are both versions of metaphysical idealism which have no relevance to the real world".

At this point we shall also critically examine the claim by African Socialism that pre-colonial African societies were classless, egalitarian and built upon the principle of equality. Studies of pre-colonial Africa have identified several kingdoms such as Ancient Ghana, Ancient Mali, Songhai, Kanem-Bornu, Hausa-Fulani, Dahomey, Ashanti, the Zulu Kingdom, Kingdom of Angola, etc. Studies show that these kingdoms had already developed state structures of force or coercion before Western intrusion. The state cannot emerge without the presence of social classes because the historical function of the state is to hold the exploited classes in subjection. After studying ancient communities Frederick Engels has made that authoritative conclusion in his book, 'Origins of the Family, Private Property and the State'. It therefore comes as a surprise that even in post-colonial Africa leaders would doubt the existence of social classes and even couch this strange idea in philosophical logic. About the Fulani Zazzau State Mair(1977, p. 79) observed that:

the 'tribute units' consisted of numbers of small towns with the hamlets attached to them. Each of these had its own head ... and the actual execution of orders from above was in this man's hands. A large fief holder would have agents in charge of different parts of his estates, and he could appoint and transfer them at will.

Kingdoms existed, traded and organized wars against each other. The Kingdom of Ghana was destroyed and upon its ruins Mali was built. Mali was in turn destroyed to make way for Songhai and so on. It should be noted that were destroyed by fellow Africans arid by Europeans. Apart from the external invasions and constant harassment by neighboring kingdoms there was always internal friction that weakened them, friction between established and emerging class tendencies. We admit that the process of Lass formation in Africa was very slow due to peculiar historical circumstances but identifiable classes and the attendant social inequalities did exist. Consequently, the much-taunted egalitarianism, freedom, equality, unity, cohesion etc. are not of much analytical value.

\section{Conclusion}

This paper has revealed clearly the critical defect in the assumption upon which Nkrumah's philosophical consciencism was erected. His effort to reject all other philosophers and construct a holistic egalitarian philosophical system upon the foundation of an objectively classless, united and cohesive society all ended up as a metaphysical, superficial, subjective, and illusive thought that has little bearing with the reality in Africa. These forces he failed to recognize and deal with right from the nationalist struggle eventually destroyed him and proved to him how real they were. President Nyerere followed the same philosophy of African Socialism and the entire Ujamaa edifice collapsed essentially because of the non-recognition of the fundamental forces working against the development of Africa. Obviously, revolutionary change is inevitable if Africa must extricate itself from Western imperialism and chart the course of her own development.

\section{Recommendations}

1. Philosophical consciencism needs a re-evaluation to accommodate some contemporary realities in Africa, particularly the existence of social classes, as a means of enhancing its applicability to the development of Africa.

2. More of such Afro-centric ideas, i.e. models of development evolved from Africa, should be encouraged and explored with the objective of constructing a modern society by utilizing the resources provided by Africa's original egalitarian precepts.

\section{References}

Ake, C. (1978). Revolutionary Pressures in Africa, London: Zed Publishers.

Ake, C. (1981). A Political Economy of Africa.Essex: Longman.

Ake, C. (2000). Social Science as Imperialism. $2^{\text {nd }}$ Edition.Ibadan: Ibadan University Press.

Babu, A. M. (1981). African Socialism or Socialist Africa? Dar es Salaam: Tanzania Publishing House.

Baran, P. (1957). The political economy of growth. Monthly Review: New York.

Brett, E. A. (1973). Colonialism and Underdevelopment in East Africa, New York: NOK Publishers.

Chinweizu (1978). The West and the Rest of Us: White predators, black slavers and the African elite. NOK Publishers Ltd.

Ekekwe, E. (2009). An Introduction to Political Economy, London: Zed Publishers. 
Emmanuel, A. (1972). Unequal Exchange, New York: Monthly Review Press.

Engels, F. (1978). Anti-Duhring: Herr Eugen Duhring's revolution in science, Peking: Foreign Languages Press.

Fanon, F. (1985). The Wretched of the Earth. New York: Penguin Books.

Fitch, B. \& Oppenheimer, M. (1966).Ghana: End of an Illusion. New York: Monthly Review Press.

Frank, A. G. (1967). Capitalism and Underdevelopment in Latin America, New York: Monthly Review.

Gramsci, A. (1999). Selections from the Prison Notebooks. London: ElecBook.

Hutchful, E. (1980). Foreign Debts and National Development, Paper presented at inauguration of the New Democratic Movement, Community Centre, Accra, 25 April.

Mair, L. (1977). African Kingdoms, London: Oxford University Press.

Marx, K. \& Engels, Frederick (1969).Selected Works Volume 1,Moscow: Progress Publishers.

McLellan, D. (1980). Marxism after Marx. $2^{\text {nd }}$ Edition, London: Macmillan Press Ltd.

Nkrumah, K. (1957). Ghana: The Autobiography of Kwame Nkrumah, NewYork: International Publishers.

Nkrumah, K. (2004). Neo-colonialism: The last stage of imperialism. London: Panaf Books.

Nkrumah, K. (1969). Consciencism: Philosophy and Ideology for De-Colonization, New York: Modern Reader.

Ogali, M. D. (2021). Peasants and Social Transformation: An essentialist approach. $2^{\text {nd }}$ Edition, Port Harcourt: S. P. Shapea Publishers.

Onimode, B. (1983). Imperialism and Underdevelopment in Nigeria. Lagos: Zed Publishers.

Rodney, W. (1972). How Europe Underdeveloped Africa. Lagos: Panaf Publishing.

Roxborough, I. (1979). Theories of Underdevelopment, London: Macmillan Press.

Selwyn, B. (2013). Karl Marx, Class Struggle and Labour-Centred Development, Global Labour Journal. Volume 4, Issue 1, January, pp. 48-70.

Wills, V. C. (2011). Marx and Morality, PhD Dissertation, University of Pittsburg. 